\title{
Pilgrimage as a Reproduction of Sacred Landscape in Finnish Karelia and the Russian Border Zone
}

\author{
TEEMU T. MANTSINEN \\ University of Turku
}

\begin{abstract}
This article examines how pilgrimages are constructed as a shared ritual of seeking sacred traces, thus creating and reproducing the sacred landscape. It studies an annual event with three connected Finnish Karelian Orthodox processions as a pilgrimage from an anthropological perspective. The event combines various motives, goals, and participants through a similar construction of the sacred landscape, with rituals of finding and creating the sacred in and for the landscape with personal experiences and stories of the imagined past. These processions, one of which crosses the border with modern Russia, attract participants motivated by both religious and heritage tourism. The article draws inspiration from Laura Stark's notion of a 'cult of traces' and engages with pilgrimage studies and theories to offer an analysis of how various acts such as religious rituals, storytelling, and taking pictures are combined in the reproduction and reinvention of the imagined past and the creation of a marked meaningful present to construct and sustain a sacred landscape, thus forming a pilgrimage.
\end{abstract}

Keywords: pilgrimage, Orthodox Christianity, sacred, ritual, tourism

Pilgrimage is often seen as a journey to a sacred centre, focusing on location, community, and rituals (Turner and Turner 1978; Coleman 2015; Della Dora, Walton, and Scafi 2015). Another perspective would be to study how and of what the sacred is constructed, and how this motivates and draws people to begin and perform their journey. In my research I followed an annual event with three processions in Eastern Finland, a location shaped by history with scattered and relocated sites of personal and cultural importance. In this article I analyse the construction of the sacred landscape as sites and goals of pilgrimage. I claim that pilgrimage is constructed around 
rituals of finding and creating the sacred landscape, and joining participants to an imagined community and history, with both individual and shared interpretations. I approach pilgrimage as an anthropological etic, not a theological emic, concept.

Although the pilgrimage in focus here technically consists of three separate journeys, they are intertwined, belonging to a continuous event. The three-day event begins with an Orthodox vigil, followed by a chapel festival the next day at Saarivaara village, continues with a procession to Hoilola during the day and a procession to the old Pörtsämö traditional Orthodox cemetery (kalmisto) in the evening, and culminates in a procession to the old and deserted Korpiselkä parish centre on the Russian side of the Finnish-Russian border the next day.

The focus here is on how participants construct landscape and pilgrimage rather than on the processions themselves. Orthodox Christian processions vary between short processions (e.g. inside a church) and long processions (e.g. between churches). Unlike many long processions to sites deemed sacred, short processions do not meet the common criteria of pilgrimages. However, I do not claim that it is the procession itself which makes the journey a pilgrimage, or its surroundings or landscape sacred. The entire event and its participants all join in various acts by which they construct the pilgrimage and landscape, building on the landscape's previous meaningmakings and stories. By 'landscape' I refer neither to static physical scenery nor an essentialist view of nature. Rather, I employ the concept from an anthropological perspective as something in and through which people live, bestow meanings upon, and construct physically, symbolically, reciprocally, socially, and by themselves (cf. Tilley and Cameron-Daum 2017).

The resurgence of Orthodox Christianity in Finland in the 1970s and the rebirth of Karelian cross processions (Laitila 1998; 2009) were important for the origins of this pilgrimage. It thus presents a different case than many Catholic and other Western European pilgrimages, which draw their inspiration, at least partly, from the Camino de Santiago - a phenomenon also called 'caminoization' (see Bowman and Sepp 2018). After the Second World War and the loss of (most of) Karelia to Russia, Orthodox Christianity was often seen as Russian, and many distanced themselves from their heritage (Kupari 2015). When the cultural landscape had changed sufficiently, Orthodox Christianity became more socially acceptable. Another basis for this pilgrimage lies in the historical importance of Karelia and its loss after the Second World War, and the imagined past and landscape it has created. 
The pilgrimage is a combination of religious, cultural, and family heritage motives and goals, with each participant having their own particular background. This article is largely based on original field research in 2016. An analysis of this research from the theoretical perspective of ritualization (see Bell 1992) and its results has previously been published in Finnish (Mantsinen and Kyyrö 2017). That article focused on the process by which various motives, goals, and modes of conduct were incorporated and negotiated into a single shared journey, constructing a pilgrimage through ritualization. In this article I look beyond the structural and organizational level to the individual and social construction of the sacred and pilgrimage through individual and collective actions.

The theoretical inspiration for my approach and this article came from Laura Stark, who studied historical pilgrimages to Valamo monastery, which she depicted as a 'cult of traces' (Stark 1995; 2002). Furthermore, in the following I consider and employ a theoretical discussion of the social construction of history, sacred landscape, sacred boundaries, the creation of the sacred, and imagined communities.

Previously, research on Karelian and Orthodox Christian pilgrimage (see Gothoni 1994; Stark 1995; Kilpeläinen 1995; Worobec 2009; Izmirlieva 2014; Bănică 2015; Rahkala 2016) has been conducted from mainly historical but also anthropological perspectives. However, the pilgrimage is not only an unambiguously religious event but extends to the realm of heritage tourism. There is substantial research on pilgrimage and heritage tourism, or heritage pilgrimage (see Adler 2002; Coleman and Crang 2002; Coleman and Eade 2004; Giovine 2011; Norman and Cusack 2014). What is new in this article is its analysis of how various acts are combined in the reproduction and reinvention of the imagined past, and marked as meaningful in the present to construct and sustain a sacred landscape in Finnish Karelian and Orthodox settings, thus forming a pilgrimage.

\section{Material and theories}

The basis of this work draws on original fieldwork. In August 2016 I travelled to Eastern Finland to study and document Orthodox Christian rituals over a weekend that included three cross processions and their associated rites. Processions were conducted on foot and in rowing boats on a river and lakes. The research methods were ethnographic participant observation and ethnographic interviews, and later interviews with and material collection from the organizing parties (the Orthodox Church and its priests, and 
the Korpiselkä parish association). During the research I found that what was happening was not merely an exclusive Orthodox religious rite but a diverse and inclusive event in a landscape replete with important cultural and personal meanings.

I call this event a pilgrimage, and parts of it pilgrimages, because it consists of travelling together to places valued as important and sacred, both individually and collectively, as I will demonstrate later. Pilgrimage researchers have emphasized communitas (Turner and Turner 1978) and contestation (Eade and Sallnow 1991) as key and not necessarily mutually exclusive factors of the process. They are always present in journeys to public cultural sites, because people share respect for or at least opinions about the site, albeit with many interpretations.

The definition of pilgrimage has often included a journey to a sacred or archaic centre (Turner and Turner 1978; Cohen 1979; Cohen 1992, 37; Schramm 2004, 137). However, in some places the site is not a single place but is scattered both physically and mentally. This correlates to what Simon Coleman and Mike Crang $(2002,11)$ call 'dissemination of place'. A stereotypical pilgrimage might be a journey to a destination to pray. The question that remains is whether the actual destination or merely a symbol, one point in the physical world, which marks and is used in constructing the imagined sacred destination, constitutes an illusion of a centre. These focal points of pilgrimage are separated from the mundane and are therefore produced as sacred symbols, but they can also play a role in serving merely as a cover for the whole experience.

Although this research does not include tourism per se, what it examines is close to a heritage journey or pilgrimage. Some researchers suggest that pilgrimage and tourism are inherently distinct, because pilgrimage travels towards the centre, while tourism disperses it (Cohen 1992, 37). However, tourism and pilgrimage often intertwine (Giovine 2011, 249). There is often a tension between tourism and pilgrimage, because people may contest the sacred space, and the boundaries between the sacred and the secular (Eade and Sallnow 1991, 11). This does not necessarily lead to desacralization; indeed, it may lead to the opposite. There are many cases in which lamenting the deprivation or loss of a sacred place actually reinforces its meaningfulness (Lane 2002, 35).

Previously, Laura Stark has analysed historical pilgrimages to old Valamo monastery on Lake Ladoga in contemporary Russia. Old Valamo monastery was a central place and influence in the Karelian religious and cultural life and universe. In her work Stark defined this pilgrimage ritual as a cult of 
traces (Stark 2002), in which participants searched for traces of saints, holy sites, and other objects of interest. A pilgrimage to a monastery differs from pilgrimages to places like chapels and cemeteries, but the theoretical invention is transferable. In both instances people seek signs of the extraordinary; only the objects vary. While monasteries offer more restricted or guarded objects of saints and of institutional importance, the pilgrimage studied here offers more accessible - border restrictions notwithstanding - objects of nature and personal importance.

Stark applies Mary Douglas's concept of the sacred as a distinction between the 'pure' and 'impure', considering its role in creating order in a community. She defines the sacred as things thought to be in contact with the supra-normal. In relation to community, she defines 'pure' as the 'value of potential growth, life, and reproduction for both society and the individual', and 'impure' as 'disorder, depletion, danger, anomaly, those things threatening social integrity and continuity' (Stark 2002, 21). In this view the sacred is a product of extending a moral contract, rules, and the conduct of social relations to supernatural beings, a result of human action (ibid., 22). According to Veikko Anttonen $(1996,77-78,95)$ the core function of the sacred is to keep things which promote and things which obstruct the community's proper functioning separate.

In this article I will use a broad definition of the sacred as distinctions not necessarily immediately or at all associated with supra-normal beings. I will approach the concept by studying things constructed as sacred by how people value them and set them apart from the mundane. In this perspective the sacred is not a meaning which people give to an object. However, as people give meaning to the object, they categorize it according to their worldview. This process constructs the sacred order in which the object is placed. As I will explain in the following, many Finns often approach Karelia and Orthodox Karelian culture as an authentic and pure Finnish culture and heritage. In other words, the things associated with these themes are sacred for many Finns.

Teuvo Laitila (1995) describes life ideals in old Karelia as exchange and renunciation. Following Laitila, Stark $(2002,175)$ identifies these as attributed to sacred boundaries of local communities, wilderness, and monastic sacred centres. Although these categories can also be identified in the pilgrimage in question here, I suggest both should be viewed as equally important, not oppositional, aspects of the issue that are ultimately not that different. Together, they constitute a landscape, and pilgrims travel in this space, reproducing them while performing their journey. 
Pilgrimages consist of various motives and goals, though some, such as visiting an important church or grave, are shared as labelling features. Although pilgrimage is usually seen as a religious practice, it contains both sacred and secular objects for participants. The elasticity of pilgrimage is important in this mixture. Elasticity is a term used by Lena Gemzöe, for example. Gemzöe claims that 'the elasticity of pilgrimage - in other words, its capacity to absorb or encompass a range of social forms - is clearly one of the features that accounts for the continuing existence and growth of the practice in post-industrial society' (Gemzöe 2016, 41).

Such elasticity is also visible in how pilgrims create the landscape through their differing interpretations of the same accounts and sites. Motives categorized as both religious and secular intertwine in them, mutually contributing to the construction of landscape and its evaluation, marking and setting boundaries and meanings within it. The practice of pilgrimage is elastic, stretching within the needs of participants, their motives, and goals. It is sacred in the making - not theologically defined and categorized, but shaped by action.

Viewing and recording sites is an important part of the journey. This is also connected with what Dean MacCannell (1976) calls 'sight sacralization', the action of naming, framing and elevating, enshrining, and reproducing mechanically and socially. How the sight is told is part of sacralization. Belden C. Lane $(2002,15)$ states that 'Above all else, sacred place is "storied place". Particular locales come to be recognized as sacred because of the stories that are told about them.'

The storied place can also be a landscape in which the event and actions occur. Landscape and tourism have also been paired in research. For example, Claudia Bell and John Lyall write of 'landscape as a dynamic arena' that activates and accelerates the sublime in adventure and ecotourism (Bell and Lyall 2002, 21). Lane proposes that a sacred place 'is a construction of the imagination that affirms the independence of the holy' (Lane 2002, 19). Imagination and shared storytelling creates a feeling of place as sacred in itself, although it is made sacred in this process.

As I approach the sacred as structured and ordered, not from the perspective of the essential or concentrated holy or axis mundi, the experienced, lived, imagined, and storied are all pivotal in understanding pilgrimage. Landscape is not an empty canvas on which to draw, but bears the previous meanings bestowed on it. Individual experiences add to and challenge existing interpretations. Veronica Della Dora, Heather Walton, and Alessandro Scafi $(2015,1-2)$ 
argue that the rich concept of landscape, rural or urban, has much to offer pilgrimage studies, notably in three key ways: i) as the visual aesthetic of any pilgrimage setting which informs and impinges on experience; ii) as the corporeally experienced ante-chamber to the pilgrimage destination; and iii) as an important facet of heritage which draws devotional and nondevotional visitors to pilgrimage sites.

The landscape informs the traveller, both in their own experiences and the many already existing interpretations. Anindividual simultaneouslyjoins in and challenges existing narratives, thus reproducing and reshaping the landscape. In broader terms these issues relate to the construction of history and identity. In old Karelia, Stark (1995) notes, objects and centres of pilgrimage (monasteries, chapels, icons) were collectively interpreted and shared in stories, recreating myths and their meanings. However, in the contemporary scene the interpretation and sharing go beyond apparent religious symbols.

\section{The imagined past as the basis for reproduction}

Stark's work on pilgrimage belonged to a larger study of peasant religious life in pre-war Karelia. Peasants performed various rituals to structure and make sense of the life around them in rural and often poor conditions. In contemporary Finland life is in many ways different. For example, the world is not explained by folk runes in village communities. That said, the contemporary pilgrimage shares many traits of these old traditions and their rituals. While the old Karelian village communities and culture are history, they serve as a paragon of the lost but idealized imagined past.

To understand what pilgrimage participants reproduce as sacred landscape, a short introduction to Karelia and the Finnish identity is required. Karelia plays a special role in Finnish national history, the construction of the Finnish nation, and nationalism. In the nineteenth century, when Finland was part of the Russian Empire, Elias Lönnrot, a Finnish cultural figure and ethnographer, travelled around Karelia, documenting its folklore, traditional songs, and customs. He used this material to create Kalevala, the Finnish national epic. Later, Zacharias Topelius, an author and professor, structured Finnish nationalism in his books, combining Kalevala and Lutheran Christianity to create a continuum of Finland's coming to be through divine providence. Kalevala and the stories and landscapes of Karelia belong to what is called Karelianism, the ism and the impact of Karelian influences on Finnish culture and society, and the idealization of Karelia in this setting (Sihvo 2017). Karelianism played a key role in the construction of the national identity through 
art and literature (Syväoja 1998). Karelia, with its runes and nature, was seen as an authentic Finnish past, representing an original good and virtuous Finnishness. Furthermore, the loss of (most of) Karelia in the Second World War strengthened its place in Finnish mythology and identity. Although Karelian evacuees were shunned for a while after the Second World War, the Karelian landscape remained a revered image of Finnishness.

The lost part of Karelia was long a place of personal contact and history. As time has passed, even personal memories have begun to fade and have been replaced by stories which interpret the past from new contexts. The imagined Karelia in contemporary Finland is only narrowly linked to empirical realism. Although it refers to actual places and recorded history, its importance lies beyond them, in identity and an emotional regime. The sites and spaces of memory in Karelia are a combination of physical and interpreted aspects of human behaviour, a utopia with a real past (Raivo 2007; Fingerroos 2006; 2008; 2010).

Access to Karelia became easier after the Soviet Union collapsed, resulting in an explosion of heritage tourism in the 1990s, when people had the opportunity to visit their birthplaces and old hometowns. However, most of the buildings have gone, which has contributed to the role of imagination in creating memories and constructing personal and family histories (Fingerroos and Häyrynen 2012). The constructed imagined Karelia is compared to personal experiences in these journeys and the pilgrimage, and reproduced with personal and embodied meanings.

Although many old sites were now accessible, some remained restricted. Visiting sites in Russian border zones requires a special permit. The Korpiselkä old parish centre is in the highly restricted zone, and religious procession rituals and visiting cemeteries are among the very few accepted reasons to receive a permit. A secular heritage tourism journey is impossible. This is also acknowledged by the clergy, who knowingly play a role in legitimizing heritage pilgrimage with religious symbols.

According to Judith Adler $(2002,26)$ journeys depicted as tourism and religious all fall under mobility, and they all have expressive and communicative purposes. A critical question can be asked about the historical validity of this claim (Coleman and Eade 2004, 10). As a shared journey, they are both invitations to join in inclusion, and belong to the idea and its history - not necessarily as part of a community of actual people but an imagined community.

Heritage tourism comes in many forms. The link between the past and present is often thin, going back generations. An example of this is ancestral tourism in Scotland. Unlike distant traces, personal connections through 
family and shared memories create an intimate relationship between a traveller and the destination when there are no multiple generations between them (Bryce, Murdy, and Alexander 2017). Another example is African-American heritage tourism to Africa. Although there are differences, there are some similarities with my research. For example, pilgrimage to Ghana provides us with a parallel case at the level of 'archaic pilgrimage': the journey is made to sites and images of past times and the premodern landscape (Schramm 2004, 137). The personal connection of heritage makes the journey sacred, even when it is not explicitly described as religious.

Our expectations and interpretations of a landscape are often driven or at least influenced by our present ideals and values, creating an imagined past (Lowenthal 1999). Our current values and worldviews guide our senses to search for expected traces. The pilgrimage simultaneously contains imagined history and traces of concrete links to the past. Participants' actions and contemporary religious rituals also keep them alive and in motion, ensuring that they are not merely static objects but a reflected and ritualized part of life. Some ancestral tombs and the churches of parents remain, and a few people born in old Karelia are still alive. However, this is changing rapidly, and personal contact is soon lost. Memories, stories, ruins and a few buildings to which they refer remain. These serve as traces of a past filled with meanings on the pilgrim's path.

\section{The pilgrimage}

The pilgrimage is organized annually by the local Orthodox church in Joensuu and the Korpiselkä parish association (Korpiselän pitäjäseura). During the three-day event a group of between forty and sixty people participate in its rituals. More people are interested in visiting the historical centre of Korpiselkä, but permit restrictions limit the numbers. Only a handful of people born in pre-war Korpiselkä are still alive, only one of whom walked there during our research visit.

The modern history of these processions and the event began in the 1970s with the resurgence of Orthodox Christianity in Finland (Laitila 1998; 2009). After the war Orthodoxy was often associated with Russia, and many evacuees concealed their tradition to fit into their new communities. As time passed, Finns became more accustomed to Orthodoxy, and the identity of Orthodox Finns strengthened. Part of this process was the reconstruction of the pre-war rituals and history of the lost territory. A new culture was also created. Procession routes (on the Finnish side) were established in the 
1970s and early 1980s. At first an anomaly, the sight of processions became part of local culture (Mantsinen and Kyyrö 2017).

When the Soviet Union collapsed in the early 1990s, the idea of a procession to the former centre of Korpiselkä was born. This was combined with existing events on the Finnish side. The current route travels from the Chapel (tsasouna) of the Transfiguration of Christ in Saarivaara to the Orthodox church of Saint Nicholas in Hoilola on foot $(10 \mathrm{~km})$, from the church shore to Pörtsämö graveyard (kalmisto) by boat $(5+5 \mathrm{~km})$, and the next day from the Finnish border zone to Korpiselkä graveyard and Orthodox church (still partly standing) on foot $(3.5+3.5 \mathrm{~km})$.

The Orthodox procession and its rituals are followed during the journey. Liturgical songs and bible verses set the pace for walking and rowing. The journey is repeatedly interrupted as the group listens to bible verses, prayers, or takes refreshments. As they move, but even more when they take a break, the participants observe their surroundings and take pictures. Before each journey and during breaks they share memories and discuss their journey and other matters. At the back of the procession group some even talk during the journey.

The routes travel through rural scenery, hills, and forests (Image 1), along less travelled roads and distant waterways (Image 2). For urban participants they offer a quiet escape from mundane life. The religious songs in the church boat travel across the water, creating an emotional landscape that somewhat resembles the old Karelian rune singers, transformed into or replaced by Orthodox rituals. A volunteer for the procession choir was especially drawn by this atmosphere that mixed nature and sound. It was something to which they looked forward every year.

The event and processions are also attended by non-Orthodox Christians. Those participating in the processions on the Finnish side do not necessarily have personal and family ties to the area, but may be interested in the pilgrimage for personal religious and other reasons. As I spoke with some of them, they told how they were inspired by the Karelian landscape and atmosphere, and the scents of the wooden chapels and old graveyards (Image 3). Their possible religious devotion was thus mingled with broader cultural and sensory interests - or vice versa.

The people who participate in the journey to the Russian side usually have family ties with old Korpiselkä. The journey heavily combines the religious and heritage aspects of pilgrimage. Some stood out, because they were unfamiliar with Orthodox rituals and did not know how to behave during liturgy. However, this was a familiar scene, and the organizers were 
sufficiently flexible to include everyone, demonstrating the pilgrimage's elasticity. Mutual respect strongly characterized the day. For the construction of pilgrimage and the landscape the diversity of the group was not an obstacle: it only enriched their production.

Before the journey to old Korpiselkä people shared their family stories and discussed possible mutual acquaintances and personal ties. This was the time to construct the narrative of lost Karelia and its importance for the participants. Although the sharing of memories was an important part of the previous days' events, the Korpiselkä journey added to this, because the sites there were usually inaccessible. While the focus of storytelling on the previous days was the experience of the landscape, the focus on the last day was the shared and imagined ancestral past. Contemporary expectations of the approaching journey and personal feelings were combined with shared stories of families and the landscape, evoking the imagined past for reconstruction and reproduction.

Borders evoke emotions and meanings. Crossing the Finnish-Russian border in Karelia was an important ritual for the participants. Given the history between the countries, it offered many levels of meanings and symbols for the imagination. For the participants the other side was not mundane, though it was desecrated by the wildly growing vegetation. Many took pictures; everyone stared at the sight of border poles stretching to the horizon, while moving forward guardedly and in an ordered manner.

When crossing the border, one participant commented, 'These are our lands.' When asked if their family had lived nearby, they said that they meant that this was Finnish land. The land, simultaneously concrete and imagined, was sacred. Not everyone was as enthusiastic, though all shared a sentiment of the lost past. Conversation was sparked by every sign of old structures, and pictures were taken. People tried to locate the sites of former buildings and speculated about what they saw, giving meaning to and categorizing their surroundings.

The main pilgrimage destination was the old Orthodox church, but the pilgrimage travelled first to the graveyard. Memorial panikhida services (panihida) were conducted at both the Orthodox (Image 4) and Lutheran sides of the graveyard, after which there was free time to search the land and visit old graves if their location was known (Image 5). Most of the stones and crosses were taken by the Soviet army after the war, leaving the site in a natural state, empty and waiting for interpretations and asserted meanings.

Those with explicitly religious motives travelled close to the priests, while those more interested in heritage tourism remained at the back. This 
highlighted the pilgrimage's elasticity, giving space for various motives and actions. With the first sight of the church, participants, especially at the back, suspended the procession to take pictures (Image 6). When we arrived at the church (Image 7), everybody inspected the church and its recently collapsed second tower. Storytelling and speculation arose in the group as they tried to salvage every moment for their memories. They compared old pictures and memories, and personal or family experiences, with the scene before them. Lamenting the devastation of a now glorified and imagined past reinforces its meaningfulness (Lane 2002, 35). Physical contact made a partly ruined church more important than before the journey.

After lunch free time was planned for people to visit nearby old sites. One group searched for the stones of a farmhouse, another for the foundations of a parsonage. A group I followed searched for the ruins of an old Lutheran church. As we walked along the road, one of the participants had a sudden realization and rushed into the forest to the site of the ruins. Only stone foundations remained, covered with trees and vegetation (Image 8). The search for old ruins, signs of the imagined past, was successful. These other ruins offered competing sacred sites for the pilgrimage, but they were instead merely incorporated into the larger fabric of the imagined past. The competing sites provided individual variety, but the ritual process was the same. This process combined stories and mental images with material traces on which meanings were bestowed and from which interpretations arose.

The pilgrimage concluded with a memorial service for the fallen soldiers of the war, an exchange of gifts with Finnish and Russian border guards, and a procession back to Finland. Many participants had been on the pilgrimage several times, and they revisited and reconstructed their own memories and shared them with newcomers. Pictures and stories were passed on and reflected on at home and on social media, expanding the impact of the pilgrimage to others.

\section{Analysis}

The communitas of the pilgrimage participants included various specific motives for joining (religious, cultural, devotional, heritage), and people came from various backgrounds - most, however, from an urban landscape. An important player here was the Orthodox priest, Father Vesa, who led the group with charismatic authority. He acknowledged the various motives and backgrounds, legitimizing different actors in a single setting. In 
a sense, he was the symbol of this momentary community. Through him and other Orthodox figures the religious label of processions not only gave the pilgrimage access to the Russian side; it also created an atmosphere of reverence and authority.

The elasticity of pilgrimage (see Gemzöe 2016) was demonstrated in action, because the priests and organizers were well aware of the participants' many motives and backgrounds. Even when some sacred boundaries were contested by others' understanding (e.g. prayer rituals), they were included in the pilgrimage's broader setting. According to Eade and Sallnow $(1991,15)$ the object and goal of the pilgrimage compiles and merges its participants' many interpretations, motives, and hopes. All the various traits of the pilgrimage studied here begin and return to the shared goal of searching for the sacred. Participants have their own interpretations of and ideals for what is important in their journey, and they search for their traces accordingly. The environments of the journey give only a few fixed points or physical sites, but a scattered field of possible traces. Participants work in their pilgrimage with both shared and individual rituals. As there are various rituals and interpretations, a need for structure arises. Fortunately, the Orthodox procession rituals and the leading priest offered frames within which people could navigate.

Orthodox rituals were the most obvious in these pilgrimages. However, other rituals were at least as visible, if not as obvious. These included the ritual of sharing and co-authoring stories of the past and the landscape, rituals of marking and recording sites, viewing and ascribing meanings to them, and evaluating and separating locations by their importance. Although one could argue that taking pictures is a mundane activity, it is still inspired by our fascination with breaking the status quo and marking an object of special interest. During the pilgrimage pictures were one way of creating meaningful memories and retrieving history. The ever-changing character of nature meant sites and objects of interest were scattered around. Apart from some ruined churches, chapels, and newly erected crosses in graveyards, they were also difficult to find. This highlighted the ritual of searching for traces. Furthermore, since the objects of interest were scattered - including the physical ones - there was no prepared pilgrimage structure. It had to be constructed and reconstructed by everyone, even by those who had previously participated.

The pilgrims repeatedly crossed paths and boundaries in and for the landscape with their bodies, enforcing its classification and socially comprehended structure and story in the experienced environment, recreating 
the sacred with their actions. This can also be seen both as a fight against or incorporation and utilization of nature, which constantly sought to obscure the traces and make the potentially sacred mundane. Especially during the first day's journey the participants constructed the sacred landscape through adoration of nature, mixed with and through the imagined other and stories of the past. The crossing of the national boundary the next day actually reinforced the landscape's sanctity. While outside forces (states) try to scatter the landscape, the imagined past and the stories about it bind cross-national lands. In walking, touching, and reclaiming the land, the participants reinstate lost Karelia in the landscape. In leaving the land, they reproduce its otherness and sanctity, combining it with strong emotions and meanings.

The scattered landscape and people's construction of pilgrimages in them approaches what Della Dora, Scafi, and Walton (2015) write about the ruins of Manx Keeills, and the prayer walks organized to experience them. The embodied practice of walking through the landscape is utilized by the narrative mind (see Johnson 1987, 171-172; Abbott 2003; Gallagher 2006), a human tendency to construct stories of what they see and experience, to make sense of them. In pilgrimage the narrative mind leads to storytelling, which can be understood as a ritual action.

Storytelling was an important ritual throughout the event. It had several functions: entering into a community and legitimizing one's place in it, sharing stories and helping others to join in them, and co-authoring a larger story while locating oneself and the perceived landscape within it. In comparing personal and national stories before and during the journey, people traced their steps in the landscape and joined the community. This notion resembles what Victor and Edith Turner (1978) call an interaction of communitas and structure in which each changes the other.

The storytelling was also a key act of marking sites, boundaries, and the landscape. These acts of marking were conducted in various ways: taking pictures; touching; observing; and contemplating. From these the stories emerged. This can be described as what MacCannell (1976) calls 'sight sacralization'. People search the scattered scene, and by evaluating and marking certain sites they create structure, boundaries, and identify centres around which their personal and group's shared pilgrimage intertwines. Together, they create and recreate storied places, affirming their sanctity in their minds (cf. Lane 2002). Connecting their experiences with stories of past, they reproduce the sacred landscape through stories of extraordinary sacred sights. 
According to Bell and Lyall (2002, 28-35) action-motivated tourists accelerate the sublime with bodily actions of travel and self-fulfilment in documenting the journey, taking pictures, and connecting with the landscape at emotional and narrated levels. Pilgrimage as a bodily effort and performance shares many of these aspects. While participants seek traces of the past in the landscape and assert meanings in sites, they accelerate sensations of the sublime in this ritual. Connecting imagination, imaginaries and family memories with the experience and landscape enforces the emotional level of the pilgrim's life, evoking a sense of something important and worth conserving - the sacred.

On the Korpiselkä journey pride in family and the national heritage played a distinctive role, culminating in metaphors of owning, belonging, and authenticity. The loss of Karelia remained a sore point for some, though the memory was fading into mythical stories. As the participant who spoke of 'our land' demonstrated, possession can be directed at a national and heritage origin story, imagined Finnishness, and personal family identity. While acknowledging that there is no return to the past, visiting old Karelia evokes not only family memories, but an imagined identity and sacred national story. By stating ownership the participant could reproduce the landscape as Finnish, if only in the imagined realm.

These metaphors are one tool used in constructing the sacred landscape. Through language rituals (cf. Rappaport 1999) people make value judgments, classify and categorize objects and ideas, thus making distinctions between the sacred and secular. With language they link the pilgrim identity with national and local history. Through their actions they participate in and join the landscape of history and heritage, including the Orthodox past, which can be used as a prototype and symbol of the 'authentic Karelia' and its culture. The experience of pilgrimage evokes charismatic encounter, in which the Eliadean timeless and Durkheimian social temporal sacred meet (Eade and Sallnow 1991, 14-15). Both the temporal group experience and connecting to the imagined other, here, past history, and its narratives are important.

The term 'imagined community' is best known from the work of Benedict Andersson (1983), who used it to describe nationalism. It also correlates to other uses of 'social imaginaries' (cf. Taylor 2003; Calhoun 2016). Here, pilgrimage participants can be seen as joining in both temporal ritual and larger national communities. Both these belongings are illusory in the sense that interpretations and experiences of their identity, 'raison d'être', and meanings are neither given nor the same, although people claim membership of them. 
The past has been obscured by faded memories, stories, and imaginaries, leaving the symbols of connection from which people can construct their stories. Anderson saw nationalism as a way to create or imagine a community. I would argue that pilgrimage offers similar tools for creating or joining stories about communities. The Karelian pilgrimage offers symbols, goals, and sites of reference, and it is also connected with the national imaginary. Family heritage and nationalistic tendencies are frequently inseparable.

Turner and Turner describe pilgrimage as a ritual journey from the mundane or profane to the sacred centre (Turner and Turner 1978, 9, 23). However, the pilgrimages I observed do not have a single physical sacred site or centre. There are many sites, even if some are more popular than others. Apart from cemeteries, personal connections are weak. Instead, the sacred centre is located in both the shared and personal mental worlds of imagined Karelia and the imagined past. In this setting boundaries of wilderness and centres of physical constructions become parts of a constructed sacred landscape organized by people through their actions.

This also correlates with what Stark (2002) and Laitila (1995) previously claimed about the old Karelian worldview. According to Stark a pilgrimage towards a centre and community's sacred boundaries entailed 'two strategies [...of...] managing purity, social order, and social continuity', separate but serving similar purposes (Stark 2002, 197-198). However, they are combined in one event, at least in contemporary pilgrimages. Concrete centres and scattered nature, which participants try to arrange to make sense of them, together occupy the landscape and are subjects of ritual acts.

The imagined Karelia is larger than the pilgrimage experience and its sites. What is important here are the bodily ritual experiences and actions by which individuals participate in reinventing and recreating the landscape, which they associate and link with the larger Karelian story and symbolic universe. Through rituals of travel, searching, and marking their surroundings they simultaneously organize their pilgrimage's landscape, both individually and collectively. Through categorization and valuation the participants set objects apart as sacred and organize them, thereby constituting a sacred order. This sacred order keeps the pilgrimage and its universe whole and intact, reproducing the sacred in action.

\section{Conclusion}

In this article, I have explored how the sacred landscape is created and reproduced by various actors from different backgrounds with own motives, 
brought together by a shared Karelian utopia, an imagined past, and the goal of its preservation, even though interpretations and meanings may vary.

The reproduction of Karelia and family heritage through seeking and constructing sacred traces includes and possibly necessitates the utilization of the Orthodox symbolic and ritual universe. The pilgrimage thus works in three mutually beneficial areas: the construction of the imagined Finnish Karelia; (re)introducing Orthodox Christianity to the landscape; and building a temporary community which shares the motive of the quest for the sacred. The elasticity of pilgrimage allows differing goals, motives, and actions to take place to benefit the shared goal of building a pilgrimage and its landscape. The same elasticity enables the construction of the sacred.

Since locations and sights, especially the surrounding nature, are scattered, the landscape of pilgrimage must be constructed from fragments. Through their bodily actions of marking, classifying, and categorizing people organize the landscape, joining fragile and partial memories and stories of the lost past with it. People construct the landscape of pilgrimage through seeking traces of interest and valuing them as important when they suppose they find them. These traces thus become the enacted sacred, emphasizing their place in creating order in the scattered environment.

Rituals in these Karelian surroundings illustrate how pilgrims and pilgrimages travel in and out of places deemed important, constructing them as sacred through boundaries and meaning-making. Some places serve as centres; others paint the outskirts of the landscape, constituting a structured sacred world of pilgrimage. Stories of the imagined past encounter personal embodied experiences, reconstructing and reproducing the landscape and the pilgrimage.

Since the old world is unattainable, with only its traces in stories and the partly preserved landscape and ruins, the goal and centre(s) of the pilgrimage must be repeatedly created for every participant. They participate and join in the community, and continue the lifecycle of this imagined landscape and its imagined community through rituals of seeking and finding these traces, and creating and recreating stories. By travelling certain paths, recording meaningful sites in pictures, and telling stories participants paint the landscape and organize it into a specific order, constructing the sacred and separating it from or pairing it with the secular.

TEEMU T. MANTSINEN is a researcher in the Department of Study of Religion at the University of Turku, Finland. E-mail: teemu.mantsinen@utu.fi 
References

Abbott, H. Porter

2003 Unnarratable Knowledge: The Difficulty of Understanding Evolution by Natural Selection - David Herman (ed.), Narrative Theory and the Cognitive Sciences, 143-162. Stanford: CLSI Publications.

Adler, Judit

2002 The Holy Man as Traveler and Travel Attraction: Early Christian Asceticism and the Moral Problem of Modernity - William H. Swatos and Luigi Tomasi (eds), From Medieval Pilgrimage to Religious Tourism, 25-50. London: Praeger.

Anderson, Benedict

1983 Imagined Communities: Reflections on the Origin and Spread of Nationalism. London: Verso.

Anttonen, Veikko

1996 hmisen ja maan rajat: 'Pyhä' kulttuurisena kategoriana. Helsinki: Finnish Literature Society.

Bănică, Mirel

2015 Music, Ritual and Community among Romania's Orthodox Pilgrimages. Review of Ecumenical Studies 7 (3), 460-465.

Bell, Catherine

1992 Ritual Theory, Ritual Practice. Oxford: Oxford University Press.

\section{Bell, Claudia and John Lyall}

2002 The Accelerated Sublime: Thrill-Seeking Adventure Heroes in the Commodified Landscape - Simon Coleman and Mike Crang (eds), Tourism: Between Place and Performance, 21-37. New York: Berghahn Books.

\section{Bowman, Marion and Tiina Sepp}

2018 Caminoisation and Cathedrals: Replication, the Heritagisation of Religion, and the Spiritualisation of Heritage. Religion 49 (1), 74-98.

Bryce, Derek, Samantha Murdy, and Matthew Alexander

2017 Diaspora, Authenticity and the Imagined Past. Annals of Tourism Research, 66: 49-60.

\section{Calhoun, Craig}

2016 The Importance of Imagined Communities - and Benedict Anderson. Journal on Culture, Power and Society 1, 11-6.

Cohen, Erik

1979 A Phenomenology of Tourist Experiences. Sociology 13 (2), 179-201. 
1992 Pilgrimage and Tourism: Convergence and Divergence - E. Alan Morinis (ed.), Sacred Journeys: The Anthropology of Pilgrimage, 47-64. Westport: Greenwood Press.

\section{Coleman, Simon}

2015 Pilgrimage. In: International Encyclopedia of the Social E Behavioral Sciences, 2nd edition, 146-48. Amsterdam: Elsevier.

\section{Coleman, Simon and Mike Crang}

2002 Grounded Tourists, Travelling Theory - Simon Coleman and Mike Crang (eds), Tourism: Between Place and Performance, 1-17. New York: Berghahn Books.

\section{Coleman, Simon and John Eade}

2004 Introduction: Reframing Pilgrimage - Simon Coleman and John Eade (eds), Reframing Pilgrimage: Cultures in Motion, 1-25. London: Routledge.

\section{Eade, John and Michael J. Sallnow}

1991 Introduction - John Eade and Michael J. Sallnow (eds), Contesting the Sacred, 1-29. London: Routledge.

\section{Della Dora, Veronica, Heather Walton, and Alessandro Scafi}

2015 Christian Pilgrimage, Landscape and Heritage: Journeying to the Sacred. New York: Routledge.

\section{Di Giovine, Michael A.}

2011 Pilgrimage: Communitas and Contestation, Unity and Difference An Introduction. Tourism 59 (3), 247-69.

\section{Fingerroos, Outi}

2006 The Karelia of Memories: Utopias of a Place. - Folklore 33, 95-108.

2008 Karelia: A Place of Memories and Utopias. - Oral Tradition Journal 23 (2), 235-54.

2010 Karjala utopiana. Jyväskylä: Nykykulttuuri.

\section{Fingerroos, Outi and Maunu Häyrinen (eds)}

2012 Takaisin Karjalaan. Helsinki: Finnish Literature Society.

\section{Gallagher, Shaun}

2006 The Narrative Alternative to Theory of Mind - Richard Menary (ed.), Radical Enactivism: Intentionality, Phenomenology and Narrative, 223-9. Amsterdam: John Benjamins.

\section{Gemzöe, Lena}

2016 Big, Strong and Happy: Reimagining Femininity on the Way to Compostela - Willy Jansen and Catrien Notermans (eds), Gender, Nation and Religion in European Pilgrimage, 37-54. London: Routledge. 


\section{Izmirlieva, Valentina}

2014 Christian Hajjis: The Other Orthodox Pilgrims to Jerusalem. Slavic Review 73 (2), 322-46.

\section{Johnson, Mark}

1987 The Body in the Mind. Chicago: The University of Chicago Press.

\section{Kilpeläinen, Hannu}

1995 Pilgrimage in Valamo Monastery in the 1930s: Byzantium and the North. Acta Byzantina Fennica 7, 96-122.

\section{Kupari, Helena}

2015 Sense of Religion: The Lifelong Religious Practice of the Evacuee Karelian Orthodox Women in Finland. Helsinki: University of Helsinki.

\section{Laitila, Teuvo}

1995 Kilvoittelu ja vaihto ihmisen eettisinä suhteina luontoon karjalaisen perinteen valossa. Ortodoksia 44, 85-98.

1998 Kansanomainen ja kirkollinen ortodoksisuus Raja-Karjalassa-Pekka Nevalainen and Hannes Sihvo (eds), Karjala. Historia, kansa, kulttuuri, 383-415. Helsinki: Finnish Literature Society.

2009 Epäluuloja, välinpitämättömyyttä ja arvostusta. Ortodoksis-luterilaiset suhteet Suomessa toisen maailmansodan jälkeen ortodoksisesta näkökulmasta - Hannu Mustakallio (ed.), Terve sielu terveessä ruumiissa. Juhlakirja professori Paavo Kettusen täyttäessä 60 vuotta 27.11.2009, 339-48. Joensuu: Karjalan Teologinen Seura.

\section{Lane, Belden C.}

2002 Landscapes of the Sacred: Geography and Narrative in American Spirituality. Second, expanded edition. Baltimore: The John Hopkins University Press.

\section{Lowenthal, David}

1999 From Landscapes of the Future to Landscapes of the Past. Norwegian Journal of Geography, 53 (2-3), 139-44.

\section{MacCannell, Dean}

1976 The Tourist: A New Theory of the Leisure Class. New York: Shocken Books.

Mantsinen, Teemu T., and Jere Kyyrö

2017 Ritualisaatio historiallisen Raja-Karjalan ortodoksisissa ristisaatoissa. Uskonnontutkija, 6 (1).

Norman, Alex and Carole M. Cusack

2014 Religion, Pilgrimage, and Tourism. London: Routledge.

Rahkala, Mari-Johanna

2016 In the Sphere of the Holy: Pilgrimage to a Contemporary Greek 
Convent - Riku Hämäläinen, Heikki Pesonen, and Terhi Utriainen (eds), Helsinki Study of Religions. A Reader, 172-189. Helsinki: Helsingin yliopisto.

\section{Raivo, Petri}

2007 Unohdettu ja muistettu suomalainen Karjala - Outi Fingerroos and Jaana Loipponen (eds), Nykytulkintojen Karjala, 55-74. Jyväskylä: Nykykulttuuri.

\section{Rappaport, Roy}

1999 Ritual and Religion in the Making of Humanity. Cambridge: Cambridge University Press.

\section{Schramm, Katharina}

2004 Coming Home to the Motherland: Pilgrimage Tourism in Ghana Simon Coleman and John Eade (eds), Reframing Pilgrimage: Cultures in Motion, 131-51. London: Routledge.

\section{Sihvo, Hannes}

2014 (1973) Karjalan kuva: Karelianismin taustaa ja vaiheita autonomian aikana. Helsinki: Finnish Literature Society.

\section{Stark, Laura}

1995 Karelian Monasteries and Pilgrimage in Oral and Written Narrative: Institutional and 'Folk' Representations of the Sacred. Temenos 31, 181-214.

2002 Peasants, Pilgrims, and Sacred Promises: Ritual and the Supernatural in Orthodox Karelian Folk Religion. Helsinki: Finnish Literature Society.

\section{Syväoja, Hannu}

1998 "Suomen tulevaisuuden näen": Nationalistinen traditio autonomian ajan historiallisessa romaanissa ja novellissa. Tampere: University of Tampere.

\section{Taylor, Charles}

2003 Modern Social Imaginaries. Durham: Duke University Press.

\section{Tilley, Christopher and Kate Cameron-Daum}

2017 Anthropology of Landscape: The Extraordinary in the Ordinary. London: UCL Press.

\section{Turner Victor and Edith Turner}

1978 Image and Pilgrimage in Christian Culture: Anthropological Perspectives. New York: Columbus University Press.

\section{Worobec, Christine D.}

2009 The Unintended Consequences of a Surge in Orthodox Pilgrimages in Late Imperial Russia. Russian History 36 (1), 62-76. 
Appendix. Photographs by Teemu T. Mantsinen and Jere Kyyrö. Image 1. Procession by foot.

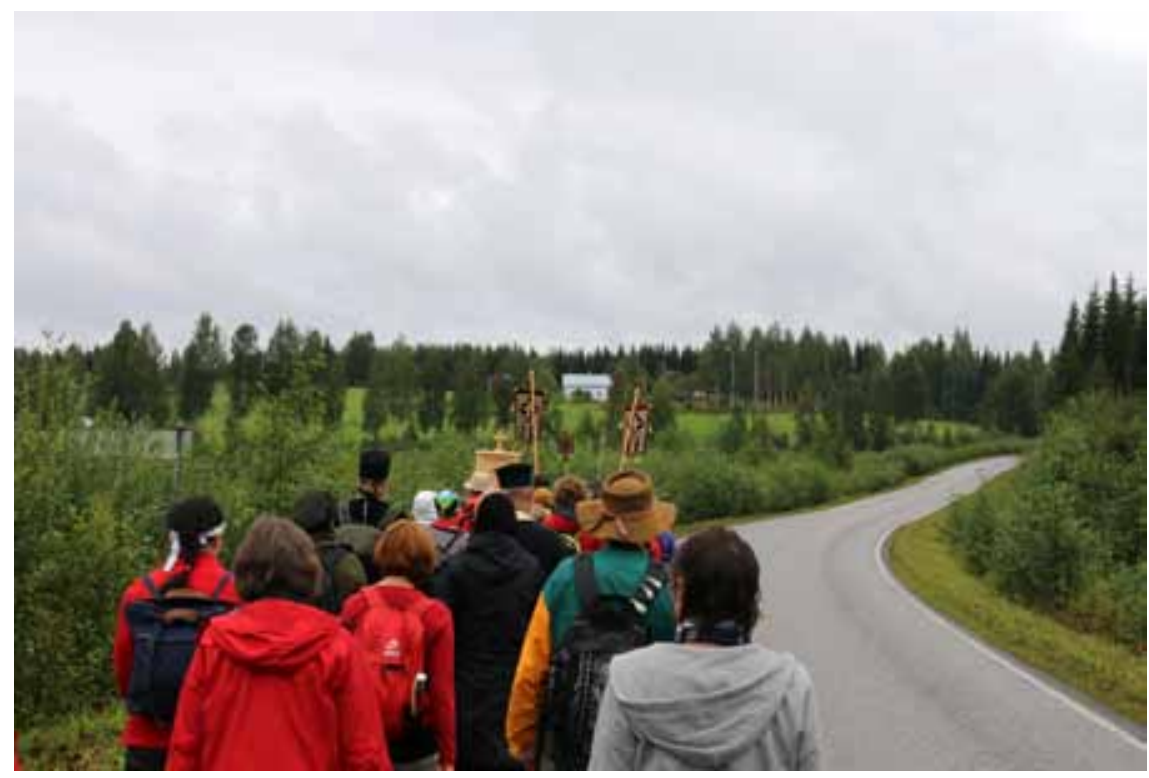

Image 2. Procession by boat.

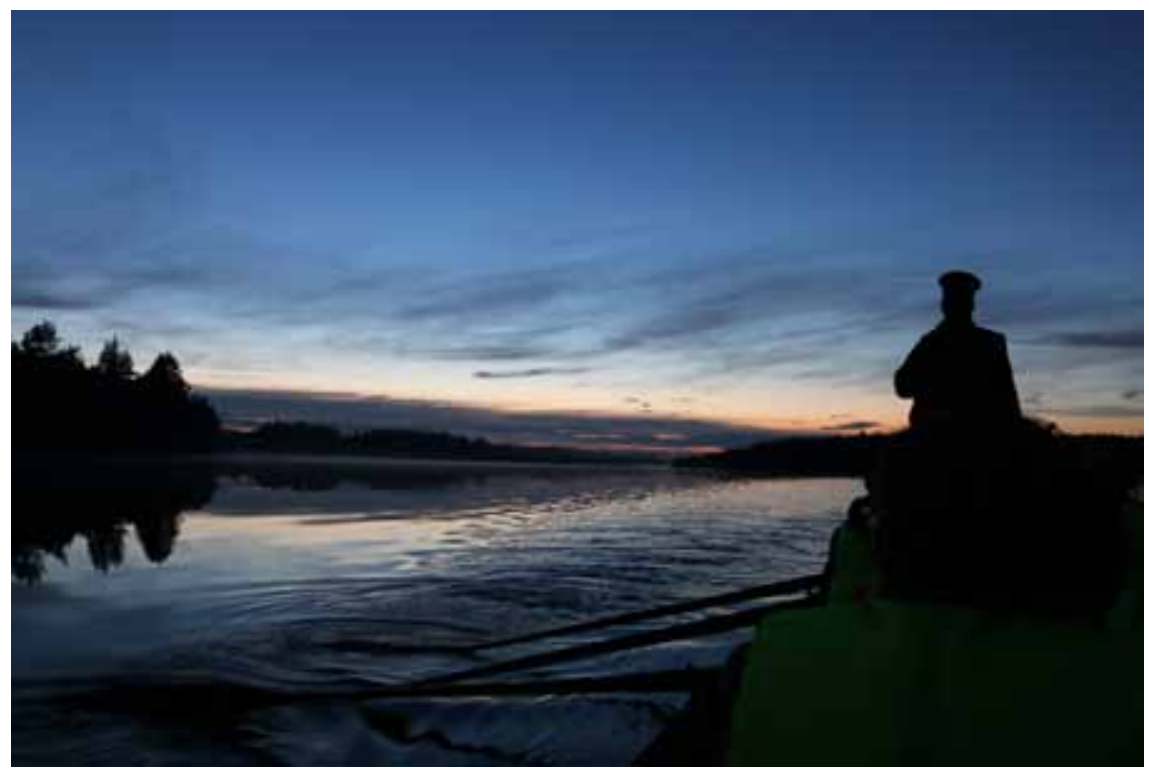


Image 3. Pörtsämö kalmisto, old graveyard.

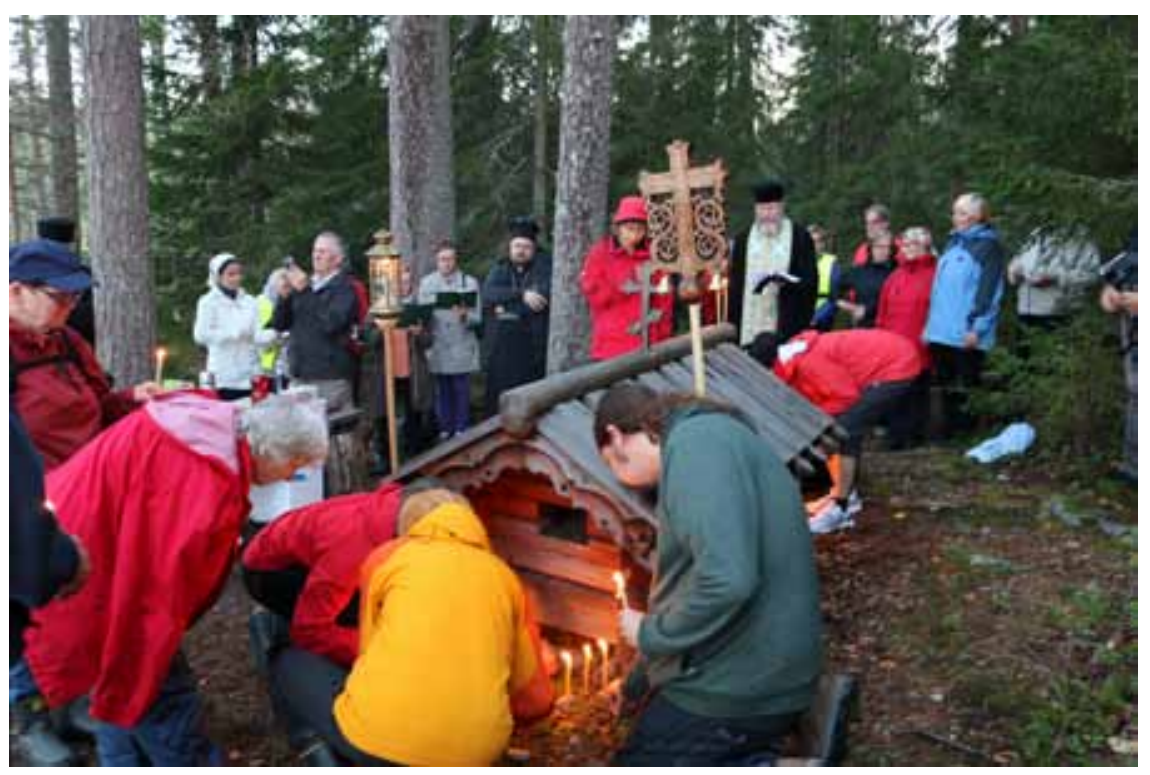

Image 4. Korpiselkä kalmisto, old graveyard.

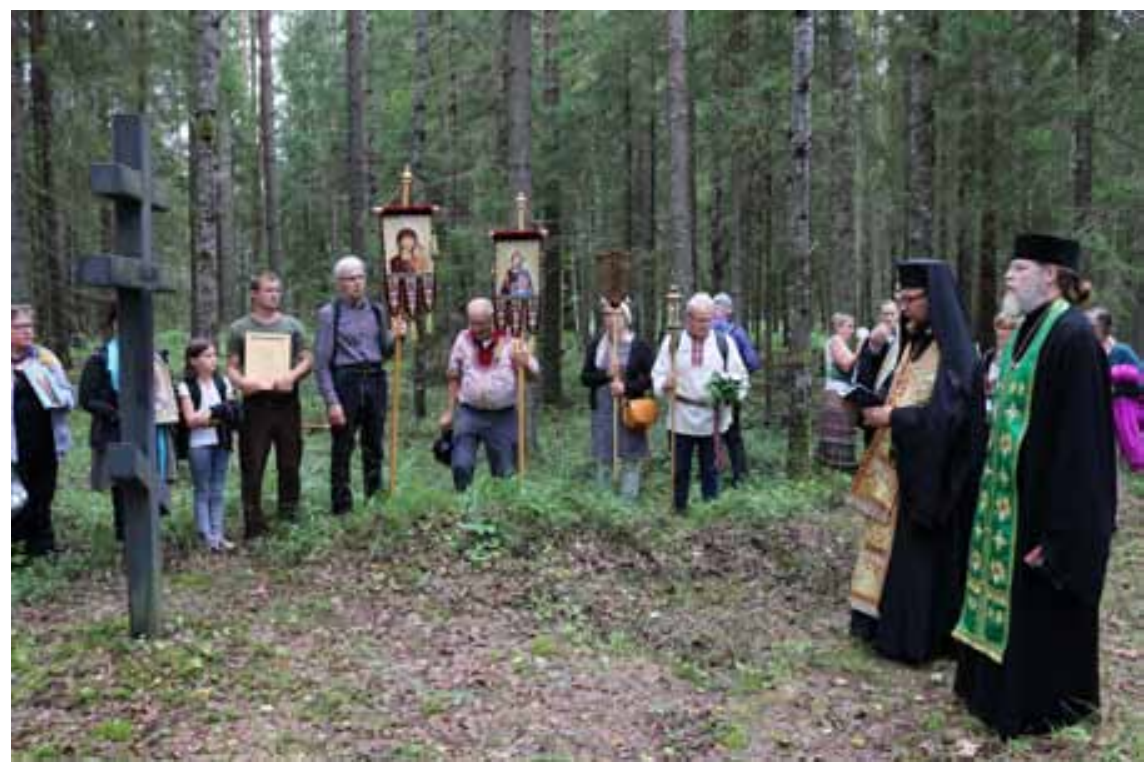


Image 5. Finding graves in Korpiselkä.

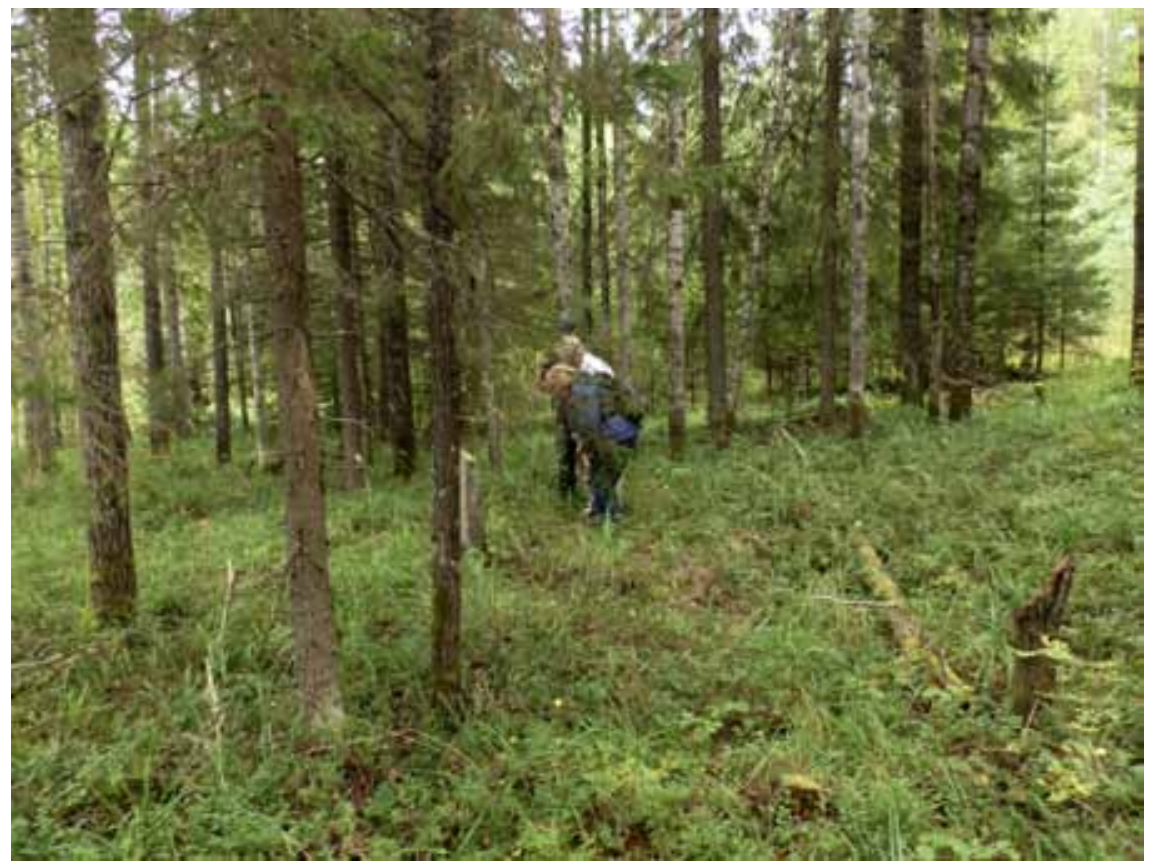

Image 6. Pilgrims approaching Korpiselkä church.

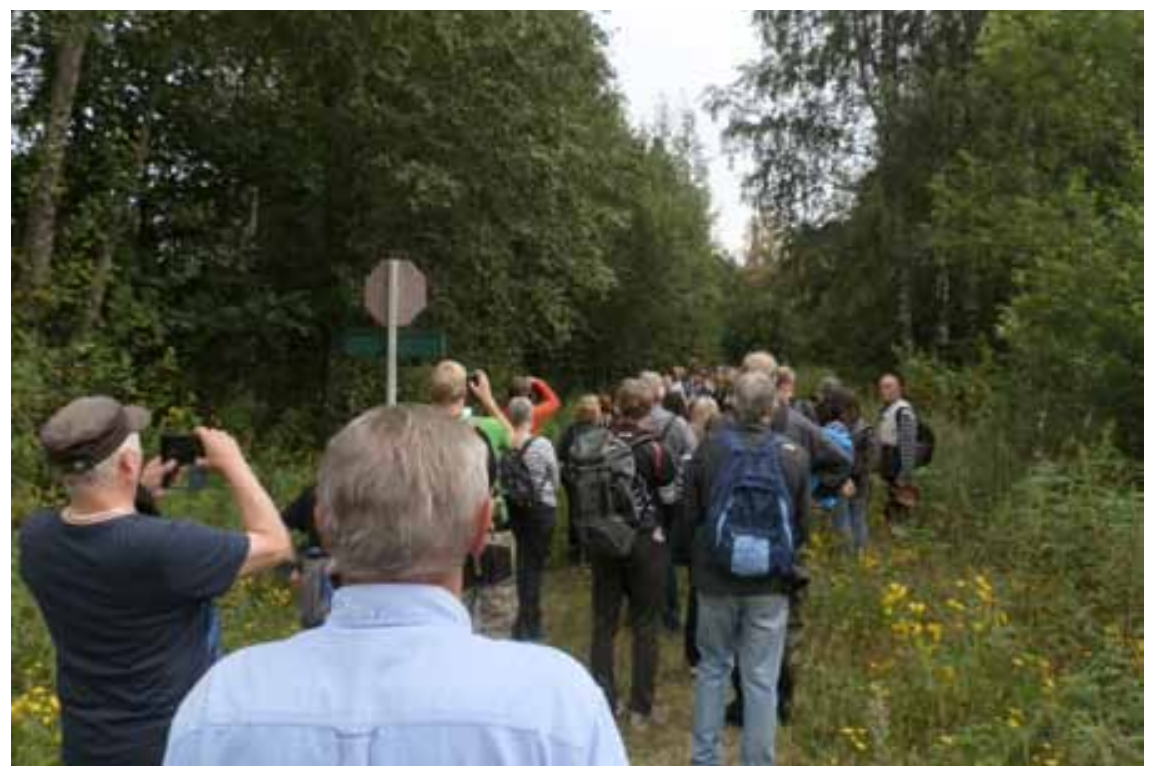


Image 7. Pilgrims arriving at Korpiselkä church.

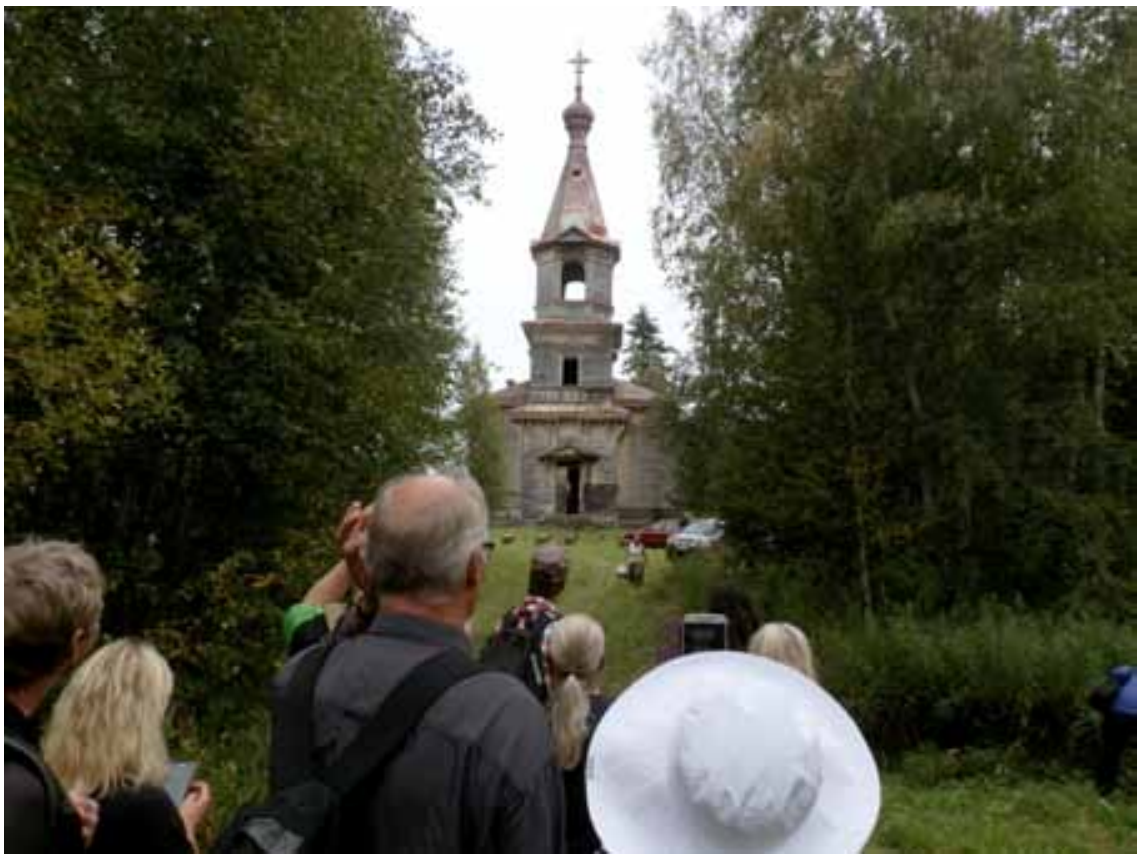

Image 8. Finding Lutheran church ruins in Korpiselkä.

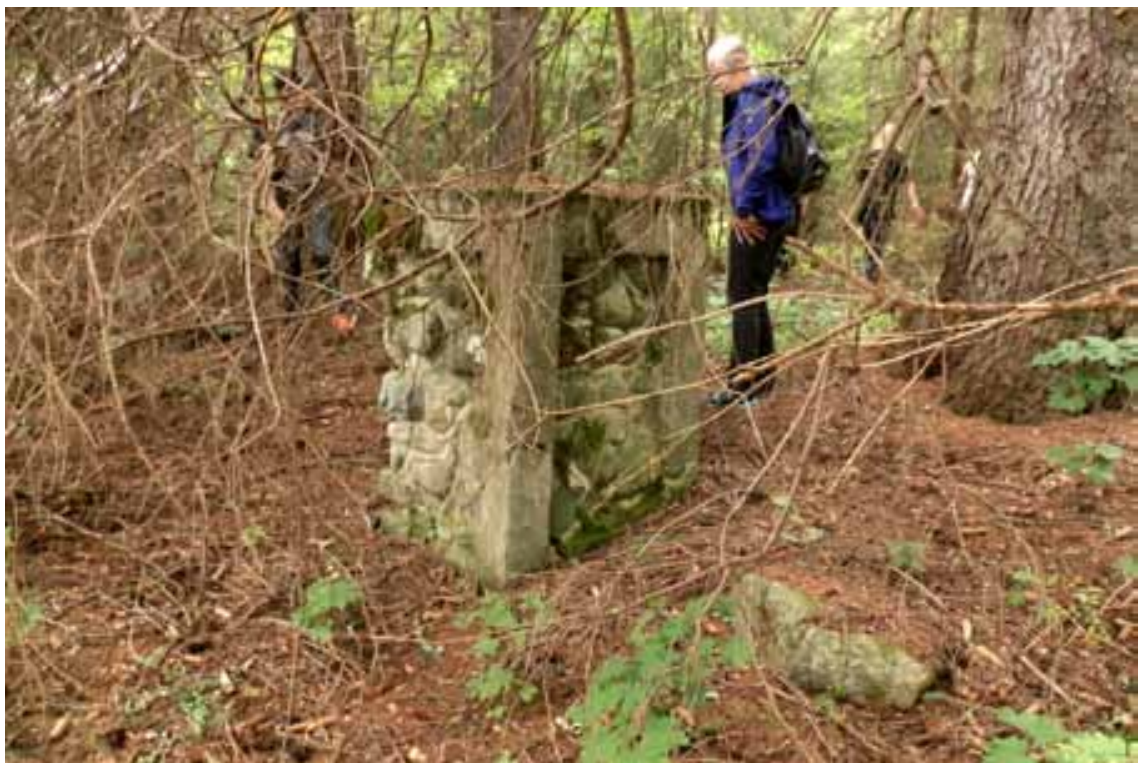


